\title{
A SIMPLE-HARMONIC MODEL FOR DEPICTING THE ANNUAL CYCLE OF
} SEASONAL TEMPERATURES OF STREAMS

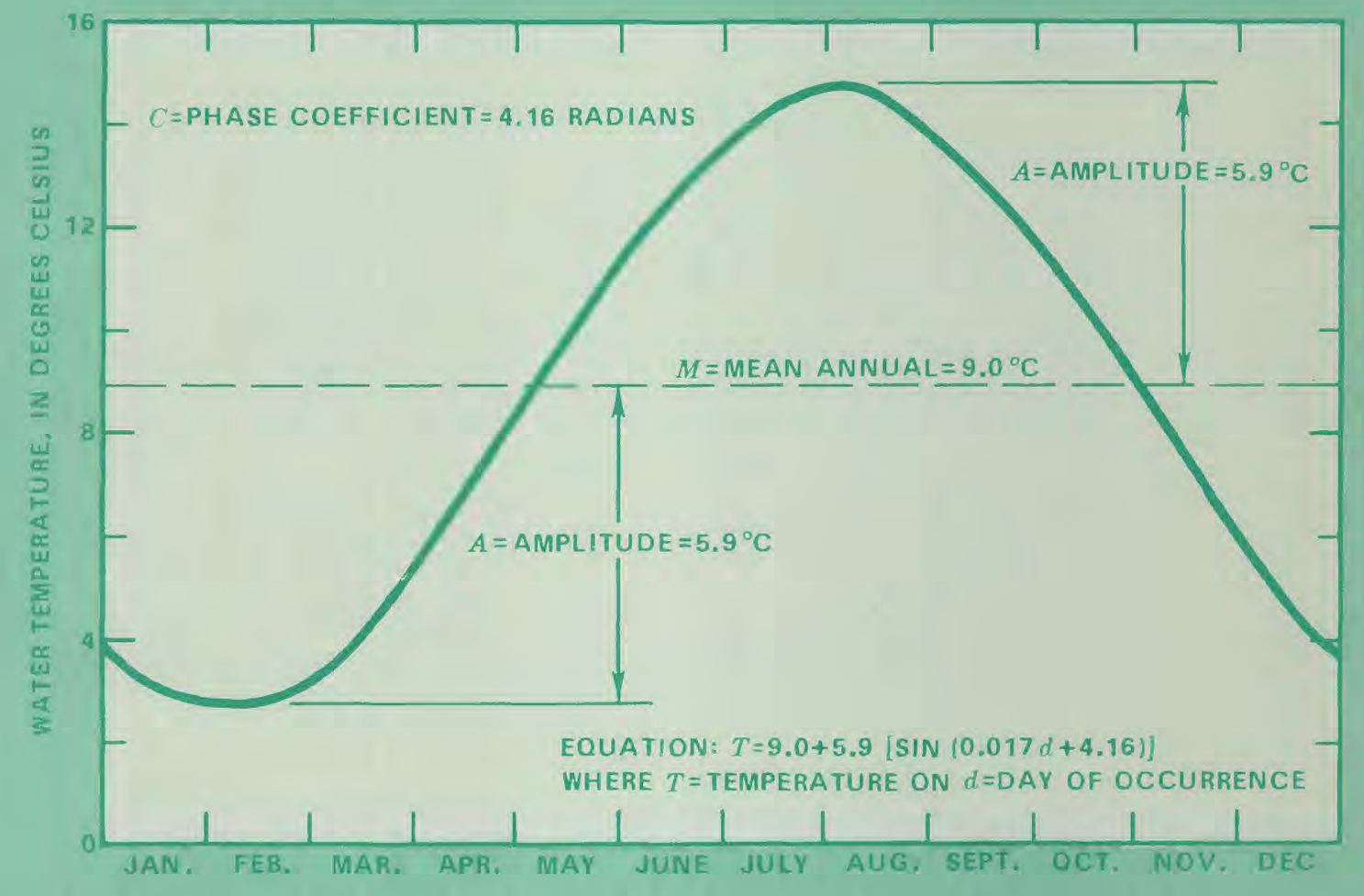



UNITED STATES

DEPARTMENT OF THE INTERIOR

GEOLOGICAL SURVEY

A SIMPLE-HARMONIC MODEL FOR DEPICTING THE ANNUAL

CYCLE OF SEASONAL TEMPERATURES OF STREAMS

By Timothy Doak Steele

Open-File Report 78-155

Paper presented at:

Symposium and Workshops on the Application of

Mathematical Models in Hydrology and Water

Resources Systems, sponsored by UNESCO, WMO,

IAHS, and IHP, Bratislava, Czechoslovakia,

September $8-13,1975$

Lakewood, Colorado

March 1978 

Abstract. . . . . . . . . . . . . . . . . . . . . . . 1

Introduction. . . . . . . . . . . . . . . . . . . . . . . 1

Approach. . . . . . . . . . . . . . . . . . . . . . . 2

Applications. . . . . . . . . . . . . . . . . . . . 6

Summary and conclusions... . . . . . . . . . . . . . . . 13

References. . . . . . . . . . . . . . . . . . . . . . 15

\section{ILLUSTRATIONS}

Figure 1. Example of computer-program B260 line-printer output for multiyear daily temperature records. . . . . . . . . 4

2-4. Graphs showing harmonic analysis of:

2. Intermittent stream-temperature data, Indus River near Darband, Pakistan. ............... 8

3. Intermittent stream-temperature data, Clearwater Piver at Draper, Alberta, Canada . . . . . . . . . . 9

4. Extreme daily temperature values for each month, Eucumbene River at Providence 2, Australia . . . . 14

\section{TABLES}

Tables 1-4. Harmonic-analys is results for:

1. Intermittent temperature data for selected Pakistan

rivers................... . 6

2. Intermittent temperature measurements, Clearwater

River at Draper, Alberta, Canada . . . . . . . . . 7

3. Daily temperature records in the Swiss Voralps . . . 11

4. Monthly data, Eucumbene River at Providence 2,

Australia................. 12 



\title{
A SIMPLE-HARMONIC MODEL FOR DEPICTING THE ANNUAL CYCLE OF
}

\author{
SEASONAL TEMPERATURES OF STREAMS
}

By Timothy Doak Steele

\begin{abstract}
Due to economic or operational constraints, stream-temperature records cannot always be collected at all sites where information is desired or at frequencies dictated by continuous or near-continuous surveillance requirements. For streams where only periodic measurements are made during the year, and that are not appreciably affected by regulation or by thermal loading, a simple harmonic function may adequately depict the annual seasonal cycle of stream temperature at any given site. Resultant harmonic coefficients obtained from available stream-temperature records may be used in the following ways: (1) To interpolate between discrete measurements by solving the harmonic function at specified times, thereby filling in estimates of stream-temperature values; (2) to characterize areal or regional patterns of natural stream-temperature conditions; and (3) to detect and to assess any significant time changes over a period of years in stream-temperature characteristics at a site brought about by streamflow regulation or basin development. Moreover, less-than-daily sampling frequencies at a given site may give estimates of annual variation of stream temperatures trat are statistically comparable to estimates obtained from a daily or continuous sampling scheme. The latter procedure may result in potential savings of resources in network operations, with negligible loss in information on annual stream-temperature variations.
\end{abstract}

\section{INTRODUCTION}

Stream temperature is one of the principal water-quality components of interest and concern in water-resources planning and management. It has a dominant effect on aquatic life in streams. Moreover, water temperature influences waste-assimilation rates and is an important variable governing stream management for recreation or municipal and industrial supplies.

Rarely can stream-temperature data be collected at every point ir time and space where such information is demanded. Therefore, techniques for transferring stream-temperature information to a desired site or at sfecific time intervals (that is, spatial and temporal interpolation and extrapolation) 
would be useful to water-resources planners and managers, assuming that the inherent errors of these transfer techniques are at acceptable levels for the intended uses of the information.

of specific concern is the quantitative description of the annual seasonal variability of stream temperatures. A simple-harmonic model was developed for and applied to a variety of thermal patterns in streams, primarily in the United States. This model is documented (Steele, 1974) and the computer program contains a number of options useful for assessing both time-series characteristics and the effects of reduced sampling frequency on resultant harmonic coefficients.

The purpose of this paper is to present the methodology constituting the simple-harmonic model and to demonstrate its applications to several case studies throughout the world. Abbreviated results of these case studies are described in this paper, and extensive computer printouts of selected casestudy results are available to interested participants of the Symposium.

\section{APPROACH}

The U.S. Geological Survey's computer program B260 can be applied to harmonic analysis of intermittent (discrete) temperature data as well as to daily (continuous) records. A complete description of the program oserations and available options is given in a program documentation report (Steele, 1974). This harmonic function model may be utilized to interpolate between discrete stream-temperature measurements and to assess the effect of various measurement-frequency schemes (Gilroy and Steele, 1972; Steele and Gilroy, 1972). Resultant harmonic coefficients may be used for summarizing areal variations in annual seasonal stream-temperature characteristics and for detecting and evaluating changes of the coefficients over a period of several years.

In computer program B260, a simple sine-function algorithm of the following form is used to define the annual seasonal cycle at a streamflow site that is commonly observed (Ward, 1963; Collings, 1969):

$$
T(t)=A \times[\sin (b t+c)]+M,
$$

where $T(t)=$ stream temperature, in degrees Celsius, on day $t$ of the annual time increment;

$A=a m p l i t u d e$ of the harmonic, in degrees Celsius;

$b=0.0172$ radians per day $=(2 \pi \div 365$ or 366 days $)$;

$C=$ phase angle of the harmonic, in radians;

$M=$ mean of the harmonic, in degrees Celsius. 
With the above notation, stream temperature $T$, at a specified site is denoted to vary as a function of time, $t$. Unless annual stream-temperature characteristics are affected appreciably by economic activity in the catcrment upstream from a sampling site, the harmonic coefficients $A, C$, and $M$ are considered to be constant in time (unless a trend is observed) and to vary principally as a function of location.

Previous harmonic analyses of stream-temperature records have shown that commonly 90 or more percent of the temperature variability is explained by the first harmonic (Thomann, 1967; Kothandaraman, 1971). Accordingly, for most practical purposes, applications of the first-order (simple) harmonic function should adequately portray the annual seasonal stream-temperature cycle.

of the harmonic coefficients $(A, C$, and $M), A$ and $M$ are of principal concern. Areal variations for $C$ (which indicates the phasing of the seasonal cycle for a specified annual increment) generally are small compared with those for $A$ and $M$, because of its primary dependence upon hemispheric climatic patterns. These latter coefficients are affected appreciably by such environmental factors as station latitude, altitude, vegetative ccver, exposure, and dominant origin of the water (that is, the proportion of ground water contributing to streamflow).

For intermittent stream-temperature measurements at a given site, an estimate of the annual maximum stream temperature is made by suming coefficients $A$ and $M$. If stream temperatures at a given site seldom reach $0^{\circ} \mathrm{C}$, the annual minimum temperature may be estimated by subtracting $A \mathrm{frcm} M$. However, in many parts of the world, a truncated sinusoidal cold-season stream-temperature pattern is observed, resulting in a short or long perict of minimum temperatures at or near freezing. The harmonic-analysis curve-fitting procedure used in computer program B260 ignores data values at or telow freezing $\left(0^{\circ} \mathrm{C}\right)$, resulting in a discontinuous harmonic function for characterizing water temperature in streams affected over a prolonged freezing period (Steele, 1974; fig. 1). An alternative to this model is to shorter the harmonic-curve periodicity to include only the nonfreezing period (Tasker and Burns, 1974).

Computer program B260, applied to records of intermittent or c'aily temperature measurements, makes appropriate adjustments for missing values or gaps in a record. However, no attempt is made in this model to account for diel temperature fluctuations in the input-data records; rather, these fluctuations are aggregated along with other unaccounted-for noise in the standard errors of estimate. Choice of the annual time-increment will affect harmonic coefficient $C$ of equation 1 ; the water year (0ctober 1 of year $n-1$ through september 30 of year $n$ ) and the calendar year are commonly used increments. Multiyear intermittent records may be fit to an aggregate annual increment; whereas, multiyear daily records may be analyzed either as separate annual increments or as a multiyear sequence. An example of the latter operating mode is given in figure 1. Program options include line-printer 


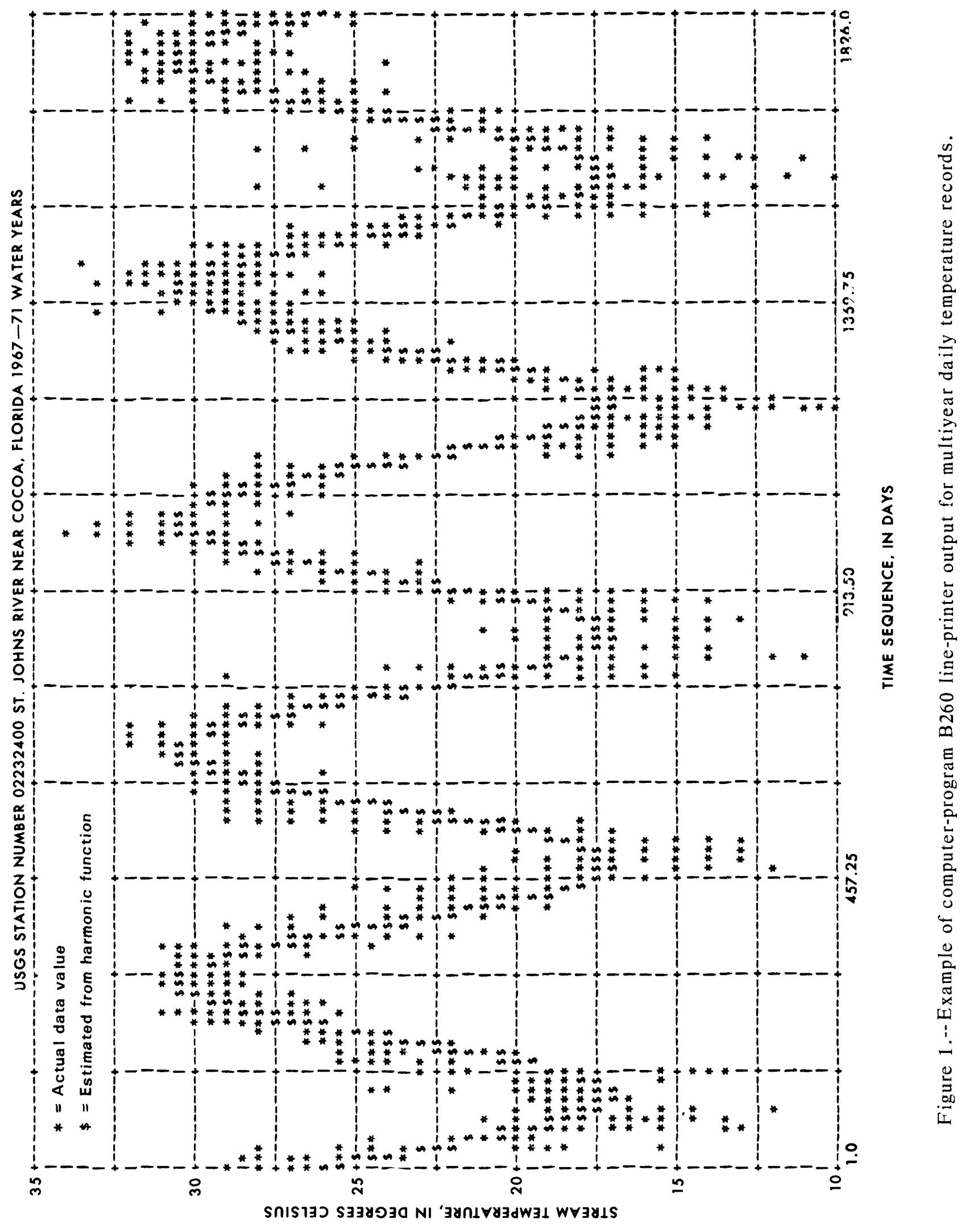




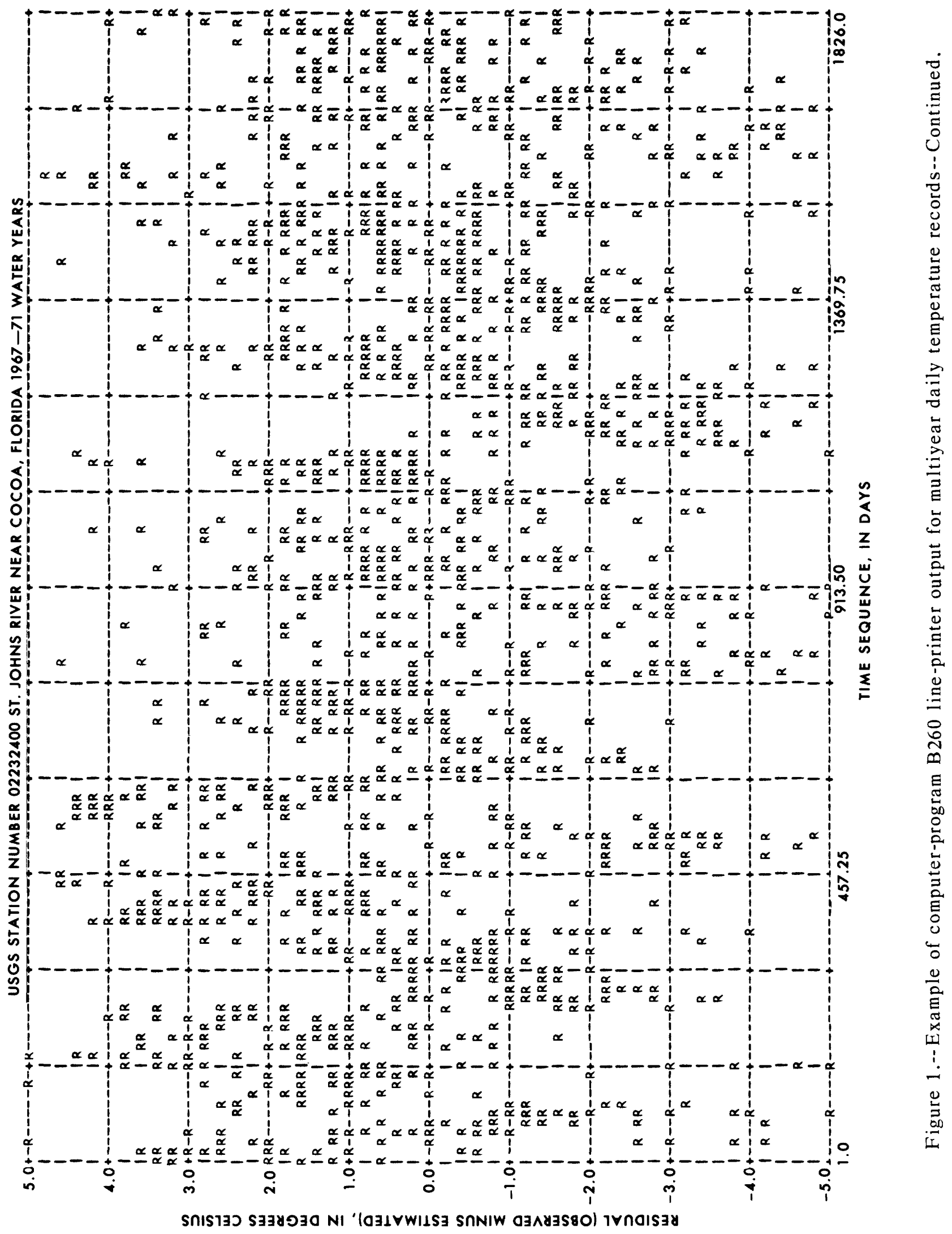


plots of observed and estimated variable time-series as well as residual plots. Several data-input format alternatives are available, and measurement unit conversions are made where needed to report results in degrees Celsius. A full description of program options and operating modes is given in the documentation report (Steele, 1974).

\section{APPLICATIONS}

Simple-harmonic analysis techniques, as described above, were applied to several statewide investigations in the United States: Arkansas (Ward, 1963), Washington (Collings, 1973), Georgia (Dyar and Stokes, 1973), Kentucky (Zogorski and Kiesler, 1976), and Indiana (Shampine, 1977). Statewide studies are ongoing for New Mexico and California--less extensive areal studies also were made in the United States (Calandro, 1973; Larson and others, 1976).

As a first case study, selected temperature data collected in conjunction with sediment records for Pakistan rivers were analyzed using rarmonicanalysis techniques (Mundorff and others, 1972). Results for 10 years of record at five stations in Pakistan are tabulated in table 1. A graphic

Table 1.--Harmonic-analysis results for intermittent temperature data for selected Pakistan rivers

[Explanation and units of $A, C$, and $M$ are given in text (equation 1)]

\begin{tabular}{|c|c|c|c|c|c|c|c|c|}
\hline \multirow{2}{*}{ Station ${ }^{l}$} & \multirow{2}{*}{ River ${ }^{l}$} & \multirow{2}{*}{ Year } & \multirow{2}{*}{ NDAYS ${ }^{2}$} & \multicolumn{3}{|c|}{$\begin{array}{c}\text { Harmonic } \\
\text { coefficients }\end{array}$} & \multirow{2}{*}{$S E^{3}$} & \multirow{2}{*}{$\begin{array}{c}\text { Percent } \\
\text { variance } \\
\text { explained }\end{array}$} \\
\hline & & & & $A$ & $C$ & $M$ & & \\
\hline $01-0105$ & Indus--- & $\begin{array}{l}1962 \\
1963 \\
1970\end{array}$ & $\begin{array}{r}215 \\
180 \\
34\end{array}$ & $\begin{array}{l}5.00 \\
4.79 \\
4.70\end{array}$ & $\begin{array}{l}4.41 \\
4.39 \\
4.44\end{array}$ & $\begin{array}{l}13.70 \\
13.08 \\
13.38\end{array}$ & $\begin{array}{l}1.45 \\
1.31 \\
1.62\end{array}$ & $\begin{array}{l}83.7 \\
99.9 \\
80.8\end{array}$ \\
\hline $01-1102$ & Siran--- & $\begin{array}{l}1962 \\
1963\end{array}$ & $\begin{array}{l}146 \\
156\end{array}$ & $\begin{array}{l}9.31 \\
7.92\end{array}$ & $\begin{array}{l}4.28 \\
4.17\end{array}$ & $\begin{array}{l}22.01 \\
21.97\end{array}$ & $\begin{array}{l}1.52 \\
2.50\end{array}$ & $\begin{array}{l}99.9 \\
83.8\end{array}$ \\
\hline $\begin{array}{l}01-1505 \\
01-1905 \\
01-1912\end{array}$ & $\begin{array}{l}\text { Soan--- } \\
\text { Kunhar-- } \\
\text { Jhel um-- }\end{array}$ & $\begin{array}{l}1967 \\
1964 \\
1961 \\
1962 \\
1963\end{array}$ & $\begin{array}{l}151 \\
102 \\
165 \\
184 \\
217\end{array}$ & $\begin{array}{l}7.47 \\
4.32 \\
6.59 \\
6.87 \\
6.40\end{array}$ & $\begin{array}{l}4.48 \\
4.16 \\
4.17 \\
4.23 \\
4.00\end{array}$ & $\begin{array}{l}23.85 \\
10.43 \\
17.27 \\
16.63 \\
17.28\end{array}$ & $\begin{array}{l}2.77 \\
1.69 \\
1.72 \\
1.80 \\
1.62\end{array}$ & $\begin{array}{l}71.0 \\
79.4 \\
99.9 \\
89.1 \\
90.6\end{array}$ \\
\hline
\end{tabular}

${ }^{1}$ For exact location, see West Pakistan Water and Power Development Authority (1960-70).

2 NDAYS=number of measurements.

${ }^{3} \mathrm{SE}=$ standard error of estimate, in degrees Celsius.

${ }^{4}$ Percent variance explained by the simple-harmonic function using the original Collings (1969) method of computation. 
example for one calendar-year $f i t$ is given for the Indus River near Darband (fig. 2). Available temperature records for Pakistan rivers are intermittent; however, the examples selected (table 1) represent some of the larger sample sizes available for annual increments (West Pakistan Water and Power Development Authority, 1960-70).

For each of the three multiple-year stations (table 1), annual streamtemperature variability is fairly persistent from year to year. Note that estimates of annual seasonal and mean variability (as depicted by coefficients $A$ and $M$, respectively) are greater for the Siran and Soan Rivers, as compared to the Indus and Kunhar Rivers, indicating the combined effects of relative higher elevation and closer proximity to snowmelt runoff from the Himalayan Mountains in the case of the latter two stations. A more thorough recional analysis of available data in Pakistan would bear out this correlative hypothesis.

For an example in North America, intermittent temperature data were analyzed for the Clearwater River in the province of Alberta, Canada (Water Survey of Canada, 1969). Results of intermittent temperature data for a single calendar year (1969) are given graphically in figure 3 and numerically in table 2. Note the truncation of the harmonic curve due to prolonged freezing conditions from January through March and November through December. If the seven freezing $\left(0^{\circ} \mathrm{C}\right)$ measurements made during the winter are included in the harmonic analysis, the mean of the harmonic function is increased, its amplitude is decreased, and the analytical depiction of the annual variatility is less accurate for the nonfreezing period, as indicated by the righer standard error of estimate caused by the lower percent variance explained (table 2) and by the dashed line in figure 3.

Table 2.--Harmonic-analysis results for intermittent temperature measurements, Clearwater River at Draper, Alberta, Canada

[Explanation and units of $A, C$, and $M$ are given in text (equation 1)]

\begin{tabular}{|c|c|c|c|c|c|c|c|}
\hline \multirow{2}{*}{$\begin{array}{c}\text { Station } \\
\text { identifier }\end{array}$} & \multirow{2}{*}{ Year } & \multirow{2}{*}{ NDAYS $^{2}$} & \multicolumn{3}{|c|}{$\begin{array}{c}\text { Harmonic } \\
\text { coefficients }\end{array}$} & \multirow{2}{*}{$\mathrm{SE}^{3}$} & \multirow{2}{*}{$\begin{array}{l}\text { Percent } \\
\text { variance } \\
\text { explained }\end{array}$} \\
\hline & & & A & $C$ & $M$ & & \\
\hline $\begin{array}{l}\text { 607CD001-. } \\
607 C D 001\end{array}$ & $\begin{array}{l}1969 \\
1969^{5}\end{array}$ & $\begin{array}{l}65 \\
58\end{array}$ & $\begin{array}{l}12.47 \\
16.57\end{array}$ & $\begin{array}{l}4.40 \\
4.42\end{array}$ & $\begin{array}{l}5.35 \\
2.68\end{array}$ & $\begin{array}{l}2.12 \\
1.60\end{array}$ & $\begin{array}{l}89.95 \\
92.39\end{array}$ \\
\hline
\end{tabular}

${ }^{1}$ For exact location, see Water Survey of Canada (1969).

2 NDAYS=number of measurements.

${ }^{3} \mathrm{SE}=$ standard error of estimate, in degrees Celsius $\left({ }^{\circ} \mathrm{C}\right)$.

${ }^{4}$ Percent variance explained by the simple-harmonic function using the original Collings (1969) method of computation.

${ }^{5} \mathrm{Cmitting}$ seven $0^{\circ} \mathrm{C}$ measurements during winter months. 


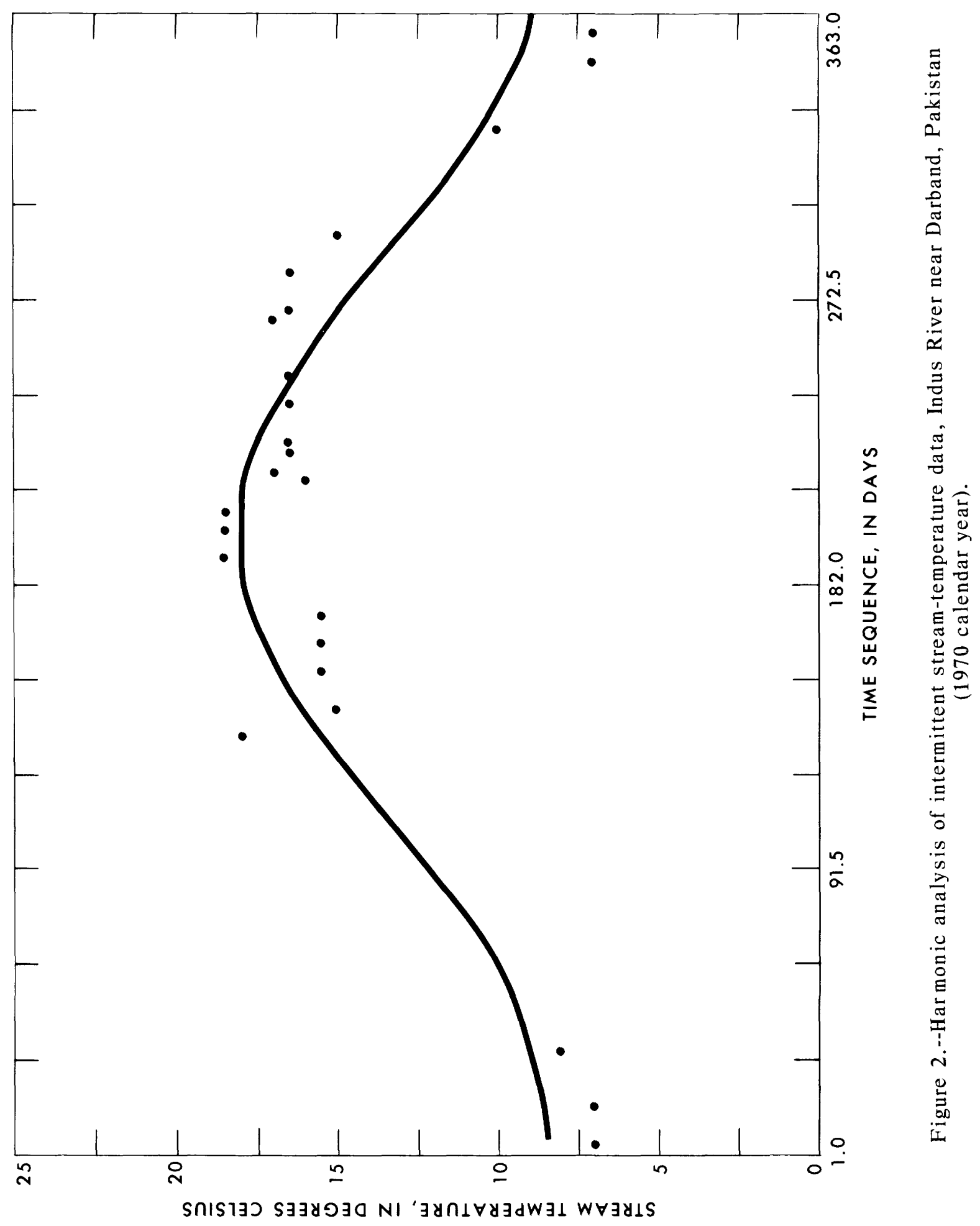




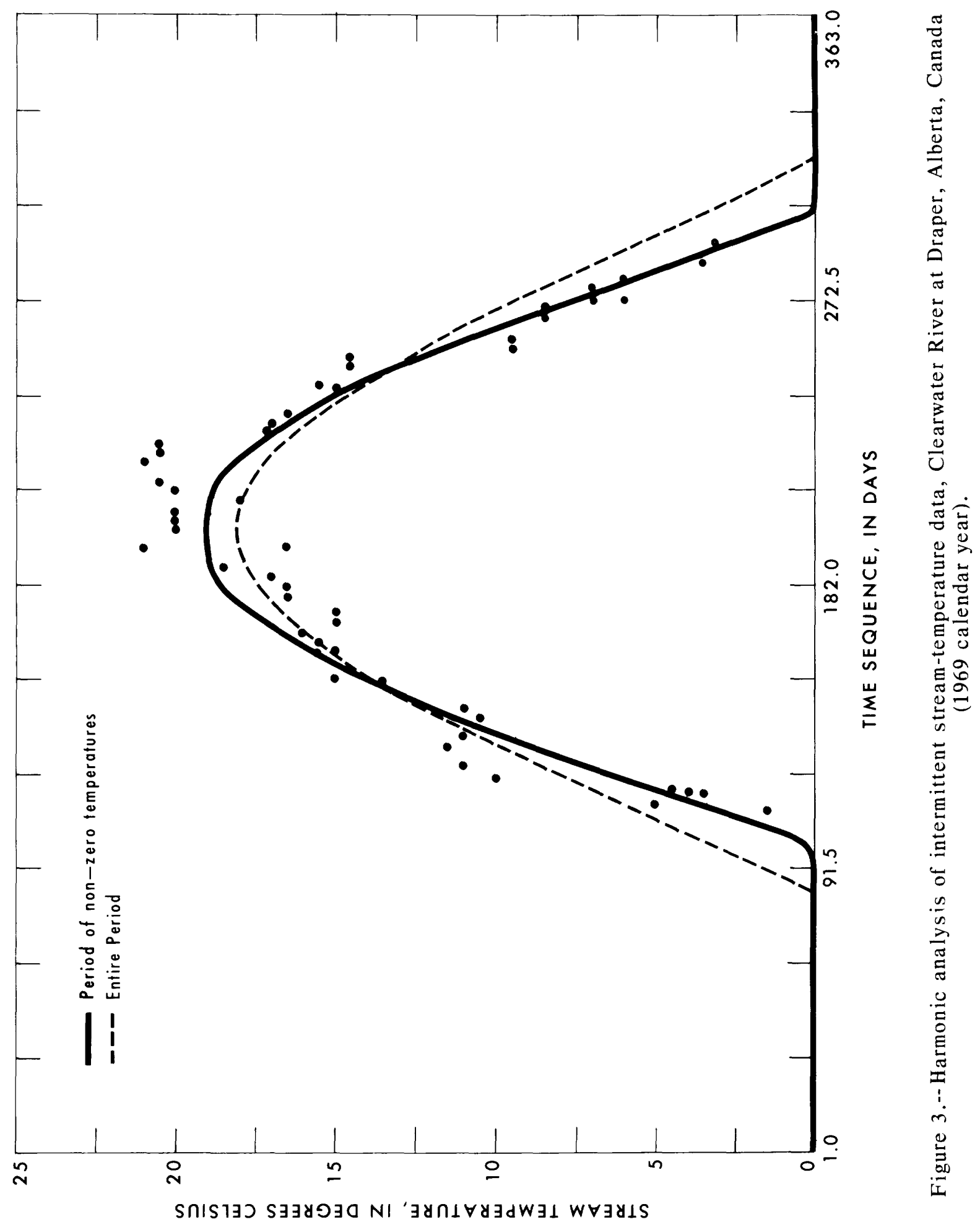


Additional uses of computer program $B 260$ are demonstrated using daily temperature records collected at three stations in the Swiss Voralps by $T$. Strobel and H. M. Keller of the Swiss Forest Research Institute (Keller, 1970). The various harmonic-analysis results obtained from these temperature records are shown in table 3 . If monthly-average stream-temperature values (station 111 for 1967 and 1968) are used for determining the harmonic function, the resultant equations are given by the first two lines of table 3 . As discussed previously, it makes a difference whether prolonged periods at or near freezing stream temperature are included or omitted from the analysis. The first line for each station year in table 3 gives the harmonic-analysis results including all near-zero measurements during freezing conditions (the number of values ranges from 345 to 365 due to recording of a few $0^{\circ} \mathrm{C}$ readings, which were omitted). The second line for each station year in table 3 gives the harmonic-function results when approximately four months of nearfreezing conditions are omitted from the analysis. As with the Canadian case study described previously, when fitting to an adjusted data set, the mean and amplitude of the harmonic function are lowered and raised, respectively, in each case.

In contrast to the previous example (data from Canada), the standard error of estimate increases (or the percentage variance explained decreases) with inclusion of freezing stream-temperature measurements, in 50 percent of the cases, in the Swiss temperature data. However, visual inspection of timeseries plots of the fitted data and resultant residuals indicates that the adjusted data (that is, omitting data for periods of near-zero conditions) are more realistic depictions of annual variability during the months of nonfreezing temperature conditions, because the residuals during the summer are more randomly distributed in time.

For each function derived using the adjusted data, the effects of several reduced sampling frequencies were evaluated. For each station year of record, harmonic functions were derived, using only every fourth, seventh, and fifteenth daily value (indicated by NMOD in the table), and resulting harmonic-function results are given in table 3. With these alternative reduced sampling frequencies, functional depiction and error values differed very little from corresponding values for the truncated daily record. These results could be anticipated, due to the high serial-correlation coefficients of the original daily record. Accordingly, this evaluation indicated that a minimal loss of information is encountered despite sharply reduced sampling schedules (Gilroy and Steele, 1972). Under certain circumstances, this factor could possibly provide savings in data-collection and processing costs.

Because of the similarity of harmonic-analysis coefficients for the Swiss stations, all three station records for 1972 and 1973 could be analyzed as a multiyear sequence, assuming an equivalent station record. Harmonic results obtained by including or omitting periods of near-zero temperatures are given in the last two lines cf table 3 . 
Table 3.--Harmonic-analysis results for daily temperature records in the Swiss Voralps

[Explanation and units of $A, C$, and $M$ are given in text (equation 1)]

\begin{tabular}{|c|c|c|c|c|c|c|c|c|}
\hline \multirow{2}{*}{ Station ${ }^{i}$} & \multirow{2}{*}{ Year } & \multirow{2}{*}{$\begin{array}{c}\text { Number } \\
\text { of } \\
\text { values }\end{array}$} & \multicolumn{3}{|c|}{$\begin{array}{c}\text { Harmonic } \\
\text { coefficients }\end{array}$} & \multirow{2}{*}{$\mathrm{SE}^{2}$} & \multirow{2}{*}{$\begin{array}{c}\text { Percent } \\
\text { variance } \\
\text { explained }\end{array}$} & \multirow{2}{*}{ NMOD $^{4}$} \\
\hline & & & $A$ & $C$ & $M$ & & & \\
\hline $\begin{array}{l}\text { III Monatsmittel } \\
\text { III Monatsmittel }\end{array}$ & $\begin{array}{l}1967 \\
1968\end{array}$ & $\begin{array}{l}12 \\
12\end{array}$ & $\begin{array}{l}5.76 \\
5.24\end{array}$ & $\begin{array}{l}4.08 \\
4.18\end{array}$ & $\begin{array}{l}5.20 \\
5.12\end{array}$ & $\begin{array}{l}1.47 \\
1.13\end{array}$ & $\begin{array}{l}89.26 \\
92.02\end{array}$ & $\begin{array}{l}-- \\
--\end{array}$ \\
\hline $\begin{array}{l}\text { Station } 111-\ldots \\
\text { Station III- } \\
\text { Station } 111- \\
\text { Station } 111- \\
\text { Station III- }\end{array}$ & $\begin{array}{l}1972^{5} \\
1972^{6} \\
1972^{6} \\
1972^{6} \\
1972^{6}\end{array}$ & $\begin{array}{r}361 \\
274 \\
69 \\
40 \\
18\end{array}$ & $\begin{array}{l}5.38 \\
5.93 \\
5.92 \\
5.70 \\
5.66\end{array}$ & $\begin{array}{l}4.29 \\
4.31 \\
4.32 \\
4.28 \\
4.22\end{array}$ & $\begin{array}{l}4.65 \\
4.34 \\
4.17 \\
4.40 \\
4.46\end{array}$ & $\begin{array}{l}1.51 \\
1.66 \\
1.67 \\
1.67 \\
1.80\end{array}$ & $\begin{array}{l}86.23 \\
80.35 \\
80.46 \\
79.97 \\
77.76\end{array}$ & $\begin{array}{r}1 \\
1 \\
4 \\
7 \\
15\end{array}$ \\
\hline $\begin{array}{l}\text { Station } 111- \\
\text { Station } 111- \\
\text { Station } 111- \\
\text { Station } 111- \\
\text { Station } 111-\end{array}$ & $\begin{array}{l}1973^{5} \\
1973^{6} \\
1973^{6} \\
1973^{6} \\
1973^{6}\end{array}$ & $\begin{array}{r}345 \\
273 \\
69 \\
39 \\
18\end{array}$ & $\begin{array}{l}6.52 \\
7.50 \\
7.32 \\
7.31 \\
7.43\end{array}$ & $\begin{array}{l}4.17 \\
4.19 \\
4.19 \\
4.18 \\
4.22\end{array}$ & $\begin{array}{l}4.86 \\
4.32 \\
4.37 \\
4.41 \\
4.14\end{array}$ & $\begin{array}{l}1.73 \\
1.71 \\
1.80 \\
1.67 \\
1.73\end{array}$ & $\begin{array}{l}87.36 \\
86.93 \\
85.50 \\
87.58 \\
87.13\end{array}$ & $\begin{array}{r}1 \\
1 \\
4 \\
7 \\
15\end{array}$ \\
\hline $\begin{array}{l}\text { Station } V \\
\text { Station } V \\
\text { Station } V \\
\text { Station } V \\
\text { Station } V\end{array}$ & $\begin{array}{l}1972^{5} \\
1972^{6} \\
1972^{6} \\
1972^{6} \\
1972^{6}\end{array}$ & $\begin{array}{r}365 \\
260 \\
65 \\
37 \\
17\end{array}$ & $\begin{array}{l}5.34 \\
6.01 \\
6.01 \\
5.68 \\
5.71\end{array}$ & $\begin{array}{l}4.31 \\
4.31 \\
4.30 \\
4.27 \\
4.22\end{array}$ & $\begin{array}{l}5.04 \\
4.67 \\
4.48 \\
4.83 \\
4.44\end{array}$ & $\begin{array}{l}1.90 \\
2.17 \\
2.17 \\
2.19 \\
2.23\end{array}$ & $\begin{array}{l}79 \cdot 69 \\
67.80 \\
67.51 \\
65.92 \\
64.54\end{array}$ & $\begin{array}{r}1 \\
1 \\
4 \\
7 \\
15\end{array}$ \\
\hline $\begin{array}{l}\text { Station } V \\
\text { Station } V \\
\text { Station } V \\
\text { Station } V \\
\text { Station } V\end{array}$ & $\begin{array}{l}1973^{5} \\
1973^{6} \\
1973^{6} \\
1973^{6} \\
1973^{6}\end{array}$ & $\begin{array}{r}360 \\
261 \\
66 \\
37 \\
17\end{array}$ & $\begin{array}{l}6.17 \\
7.63 \\
7.43 \\
7.48 \\
7.64\end{array}$ & $\begin{array}{l}4.15 \\
4.18 \\
4.17 \\
4.16 \\
4.21\end{array}$ & $\begin{array}{l}5.14 \\
4.33 \\
4.40 \\
4.39 \\
4.07\end{array}$ & $\begin{array}{l}1.63 \\
1.56 \\
1.68 \\
1.50 \\
1.50\end{array}$ & $\begin{array}{l}88.04 \\
87.72 \\
85.88 \\
88.49 \\
88.68\end{array}$ & $\begin{array}{r}1 \\
1 \\
4 \\
7 \\
15\end{array}$ \\
\hline $\begin{array}{l}\text { Station VIII---- } \\
\text { Station VIIII--- } \\
\text { Station VIII - } \\
\text { Station VIII-- } \\
\text { Station VIII - }\end{array}$ & $\begin{array}{l}1972^{5} \\
1972^{6} \\
1972^{6} \\
1972^{6} \\
1972^{6}\end{array}$ & $\begin{array}{r}347 \\
253 \\
63 \\
37 \\
16\end{array}$ & $\begin{array}{l}5.23 \\
6.43 \\
6.49 \\
6.12 \\
6.42\end{array}$ & $\begin{array}{l}4.24 \\
4.24 \\
4.24 \\
4.21 \\
4.19\end{array}$ & $\begin{array}{l}4.39 \\
3.71 \\
3.57 \\
3.87 \\
3.53\end{array}$ & $\begin{array}{l}1.39 \\
1.45 \\
1.46 \\
1.45 \\
1.67\end{array}$ & $\begin{array}{l}87.53 \\
83.46 \\
83.38 \\
83.11 \\
77.53\end{array}$ & $\begin{array}{r}1 \\
1 \\
4 \\
7 \\
15\end{array}$ \\
\hline $\begin{array}{l}\text { Station VIII---- } \\
\text { Station VIIII--- } \\
\text { Station VIIII-- } \\
\text { Station VIIII- } \\
\text { Station VIII - }\end{array}$ & $\begin{array}{l}1973^{5} \\
1973^{6} \\
1973^{6} \\
1973^{6} \\
1973^{6}\end{array}$ & $\begin{array}{r}365 \\
254 \\
64 \\
37 \\
16\end{array}$ & $\begin{array}{l}5.52 \\
7.43 \\
7.30 \\
7.23 \\
8.03\end{array}$ & $\begin{array}{l}4.16 \\
4.11 \\
4.11 \\
4.10 \\
4.15\end{array}$ & $\begin{array}{l}4.51 \\
3.61 \\
3.68 \\
3.68 \\
3.16\end{array}$ & $\begin{array}{l}1.63 \\
1.45 \\
1.52 \\
1.41 \\
1.58\end{array}$ & $\begin{array}{l}86.46 \\
88.09 \\
86.99 \\
88.72 \\
86.60\end{array}$ & $\begin{array}{r}1 \\
1 \\
4 \\
7 \\
15\end{array}$ \\
\hline $\begin{array}{l}\text { Mult i year- } \\
\text { Mult iyear- }\end{array}$ & $\begin{array}{l}1973^{5} \\
1973^{6}\end{array}$ & $\begin{array}{l}2,143 \\
1,575\end{array}$ & $\begin{array}{l}5.70 \\
6.73\end{array}$ & $\begin{array}{l}4.18 \\
4.19\end{array}$ & $\begin{array}{l}4.77 \\
4.21\end{array}$ & $\begin{array}{l}1.73 \\
1.84\end{array}$ & $\begin{array}{l}84.52 \\
80.08\end{array}$ & -- \\
\hline
\end{tabular}

${ }^{1}$ For exact location, see Keller (1970).

${ }^{2} \mathrm{SE}=$ standard error of estimate, in degrees Celsius.

3 Percent variance explained by the simple-harmonic function using the original Collings (1969) method of computation.

${ }^{4}$ !IMOD=value of $n$ for which every $n$th data value is used for fitting the harmonic function.

${ }^{5}$ Including periods of at- or near-freezing temperatures.

${ }^{6}$ Omitting periods of at- or near-freezing temperatures. 
As a final case study, monthly average-daily maximum stream temperatures for the Eucumbene River, Australia, were analyzed for 1961-68 (Snowy Muntains Hydro-Electric Authority, 1972). Curve fitting of these monthly data on an individual calendar-year basis is summarlzed in the upper part of table 4. Average-daily maximum values are missing for January through March 1961 and for November and December 1963. For the 8 years of monthly record, 91 to 98 percent of the temperature variability was explained by the harmonic function. Using the Kendall's tau nonparametric ranking procedure (Conover, 1971) for testing for trends in the several harmonic coefficients (rounded to tenths) (Steele and others, 1974), it was found that $M$ has a trend with a level of significance of 0.10 , and $A$ has a trend with a level of significance of 0.05 . When $A$ and $M$ are combined to form an annual time series for estimating the annual extreme of the average-daily maximum values for each month, this series is found to have a trend with a level of significance of 0.02 .

\section{Table 4.--Harmonic-analysis results for monthly data, Eucumbene River at Providence 2, Australia}

[Upper part of table gives $B 260$ results using monthly average-daily maximum stream temperatures. Lower part of table gives 3260 results using monthly maximum and minimum stream temperatures for 1962 and 1968, in that order. Explanation and units of $A, C$, and $M$ are given in text (equation 1)]

\begin{tabular}{lcccccccc}
\hline Station & & Year & $\begin{array}{c}\text { Number } \\
\text { of } \\
\text { values }\end{array}$ & \multicolumn{2}{c}{$\begin{array}{c}\text { Harmonic } \\
\text { coefficients }\end{array}$} & SE & $\begin{array}{c}\text { Percent } \\
\text { variance } \\
\text { explained }\end{array}$ \\
\hline 353622 & & 1961 & 9 & 6.71 & 1.60 & 9.68 & 0.74 & 97.71 \\
353622 & 1962 & 12 & 6.99 & 1.31 & 10.07 & 1.00 & 96.32 \\
353622 & 1963 & 10 & 7.54 & 1.31 & 10.55 & .84 & 97.72 \\
353622 & 1964 & 12 & 7.70 & 1.30 & 9.84 & 1.13 & 96.16 \\
353622 & & 1965 & 12 & 8.65 & 1.42 & 10.40 & 1.37 & 95.55 \\
353622 & & 1966 & 12 & 7.48 & 1.41 & 10.26 & 1.18 & 95.56 \\
353622 & & 1967 & 12 & 7.52 & 1.32 & 10.44 & 1.27 & 94.94 \\
353622 & & 1968 & 12 & 8.97 & 1.16 & 11.13 & 1.96 & 91.82 \\
\hline \hline 353622 & (Max) & 1962 & 12 & 7.96 & 1.36 & 11.58 & 1.47 & 93.88 \\
353622 & (Min) & 1962 & 10 & 4.33 & 1.08 & 5.07 & .96 & 90.44 \\
353622 & (Max) & 1968 & 12 & 10.19 & 1.21 & 12.88 & 2.62 & 88.59 \\
35.3622 & (Min) & 1968 & 10 & 6.49 & .88 & 5.28 & 1.73 & 87.24 \\
\hline
\end{tabular}

${ }^{l}$ For exact location, see Snowy Mountains Hydro-Electric Authority (1972).

$2 \mathrm{SE}=$ standard error of estimate, in degrees Celsius.

${ }^{3}$ Percent variance explained by the simple-harmonic function using the original Collings (1969) method of computation. 
Maximum and minimum stream temperatures recorded for each month are plotted in figure 4 for calendar years 1962 and 1968 . These curves tend to indicate the extent of diurnal variability through the year. Overall, stream temperatures were slightly higher in 1968 relative to 1962 (see lower part of table 4), which lends further support to the time-trend analysis results described above. The opposite phasing of the simple-harmonic function reflects the inverted seasonal climatological pattern of the Southern Hemisphere.

\section{SUMMARY AND CONCLUSIONS}

The several worldwide case studies described demonstrate the applicability and adequacy of the harmonic-analysis technique for depicting annual stream-temperature variability. Derivation of harmonic coefficients for several data sampling stations may enable planners to generalize streamtemperature patterns for specific purposes. After collecting temperature data over several years, possible significant time changes in one or more of the coefficients may be evaluated using available nonparametric statistical tests for trend detection and assessment. Adequate documentation of historical land-use and water-management schemes should provide an explanation for the observed changes.

Options in the U.S. Geological Survey's harmonic-analysis comoter program provide a means of evaluating the impact of alternative reduced frequency-of-sampling strategies--either on a systematic or stratified basis. Also, the effect of prolonged freezing of streams on analytic depiction of seasonal variations may be assessed. Several case-study analyses of daily stream-temperature records have indicated that loss of information is negligible in reducing sample frequency from a daily to a monthly schefule. Where significant changes in stream temperatures occur or are proposed, either by shifting or by distorting the characteristic seasonal cycle, the harmonicanalysis approach serves as a reference curve for assessing the magnitude and possible effects of the change. For example, this model would be quite useful in documenting possible effects of impoundments or the impact of thermaldischarge effluents from powerplants on downstream reaches. Prior distributions for Bayesian analyses could be estimated for stream sites with few or no data by using values of harmonic coefficients at sites for which temperature measurements are available. 


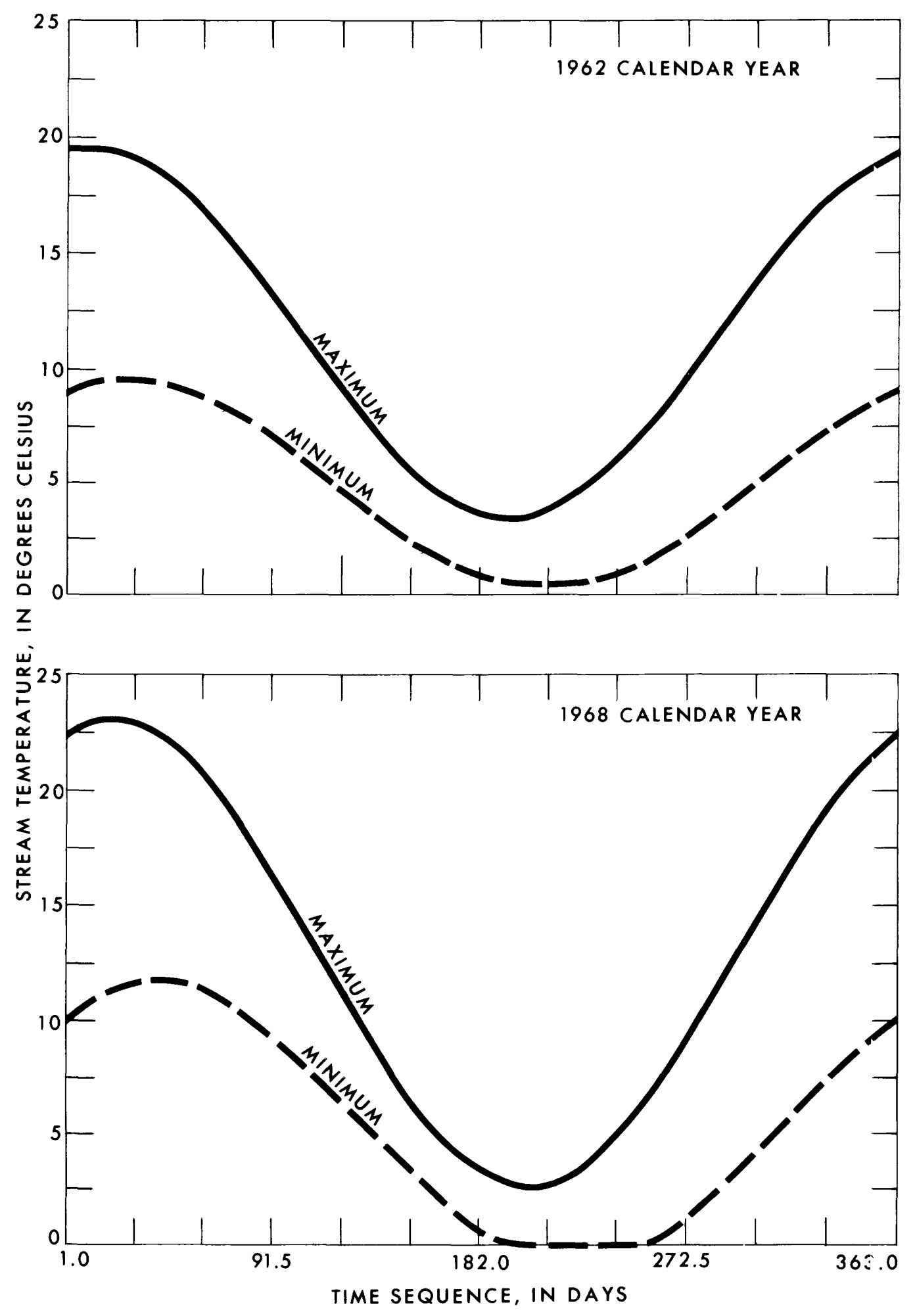

Figure 4.-- Harmonic analysis of extreme daily temperature values for each month, Eucumbene River at Providence 2, Australia (1962 and 1968 calendar years). 


\section{REFERENCES}

Calandro, A. J., 1973, An analysis of stream temperatures in Louisiana: Louisiana Dept. Public Works, Tech. Rept. 6, 16 p.

Collings, M. R., 1969, Temperature analysis of a stream: U.S. Reol. Survey Prof. Paper 650-B, p. B174-B179.

1973, Generalization of stream-temperature data in Washington: U.S. Geol. Survey Water-Supply Paper 2029-B, P. B1-B45.

Conover, W. J., 1971, Practical nonparametric statistics: New York, John Wiley $\&$ Sons, Inc., $462 \mathrm{p}$.

Dyar, T. R., and Stokes, W. R., 1973, Water temperatures of feorgia streams: Georgia Dept. Natural Resources, Environmental Protection Div., 317 p.

Gilroy, E. J., and Steele, T. D., 1972, An analysis of sampling frequency alternatives for fitting a daily stream temperature model: Tucson, Ariz., Internat. Symposium on Uncertainties in Hydrologic and Water Resource Systems Proc., December 1972, p. 594-608.

Keller, H. M., 1970, Der Chemismus kleiner Bäche in teilweise bewaldeten Einzugsgebieten in der Flyschzone eines Voralpentales: Mitteilunggen, Schweizerische Anstalt für das forstliche Versuchswesen, v. 46, no. 3, p. 113-155.

Kothandaraman, Veersamy, 1971, Analysis of water temperature variations on large rivers: Am. Soc. Civil Engineers Proc., Jour. Sanitary Eng. Div., v. 97, no. SA1, p. 19-31.

Larson, S. P., Mann, W. B., IV, Steele, T. D., and Susag, R. H., 1976, Graphic and analytical methods for assessment of stream-water quality-Mississippi River in the Minneapolis-St. Paul metropolitan area, Minnesota: U.S. Geol. Survey Water-Resources Inv. 76-94, 55 p.

Mundorff, M. J., Carrigan, P. H., Jr., Steele, T. D., and Pandall, A. D., 1972, Hydrologic evaluation of the salinity control and reclamation projects in the Indus plains of West Pakistan: U.S. Agency for Internat. Deve1., Proj. Summary Rept., PIO/T N0. 391-000-2-20189, app. Q.

Shampine, W. J., 1977, Indiana stream-temperature characteristics: U.S. reol. Survey Water-Resources Inv. 77-6, $55 \mathrm{p}$.

Snowy Mountains Hydro-Electric Authority, 1972, Water temperature records of the Snowy Mountain Region Australia, January 1972, p. 16-19.

Steele, T. D., 1974, Harmonic analysis of stream temperatures: Reston, Va., U.S. Geol. Survey Computer Contr., 246 p. (available also from U.S. Dept. Commerce, Natl. Tech. Inf. Service, Springfield, Va. 22151, report PB$239016 /$ AS).

Steele, T. D., and Gilroy, E. J., 1972, Harmonic analysis of stream temperature data [abs.]: Am. Geophys. Union Trans., v. 53, no. 4, p. 378.

Steele, T. D., Gilroy, E. J., and Hawkinson, P. D., 1974, fn assessment of areal and temporal variations in streamflow quality using selected data from the National Stream Quality Accounting Network: U.S. Geol. Survey Open-File Rept. 74-217, 210 p.

Tasker, G. D., and Burns, A. W., 1974, Mathematical generalization of stream temperatures in central New England: Am. Water Resources Assoc., Water Resources Bull., December 1974, p. 1133-1142. 
Thomann, R. V., 1967, Time-series analysis of water-quality data: Am. Soc. Civil Engineers Proc., Jour. Sanitary Eng. Div., v. 93, no. SA1, p. 1-23. Ward, J. C., 1963, Annual variation of stream water temperature: Am. Soc. Civil Engineers Proc., Jour. Sanitary Eng. Div., v. 89, no. SA6, p. 1-16. Water Survey of Canada, 1969, Sediment data for Canadian rivers: Ottawa, Canada, Inland Water Directorate, Dept. Environment, p. 56-57.

West Pakistan Water and Power Development Authority, 1960-70, Annual reports of river and climatological data of West Pakistan (volumes for sediment and quality data): Lahore, Pakistan, Surface Water Hydrology Project, WAPDA, WASID.

Zogorski, J.S., and Kiesler, J. L., Jr., 1976, Water temperatures of Kentucky: U.S. Geol. Survey Open-File Rept. 76-86, 1 map. 